\title{
In vitro Embryo culture of Croton scabiosus Bedd. (Euphorbiaceae), an endemic plant of Southern Andhra Pradesh
}

\author{
S. Salamma and B. Ravi Prasad Rao \\ Biodiversity Conservation Division, Department of Botany, \\ Sri Krishnadevaraya University, Anantapur-515003, Andhra Pradesh. India
}

\begin{abstract}
Croton scabiosus Bedd. (Euphorbiaceae) is a global endemic to Southern Eastern Ghats of Andhra Pradesh, India. Seed pathological problems, poor germination and recurrent fires in the native habitat are the major causes for low regeneration of this species. With an objective to augment the species population in the natural and allied habitats, the present study focus on developing a standard protocol for mass multiplication of the species through embryo culture. Of the various growth regulators employed for embryo culture $0.5 \mathrm{mg} / \mathrm{l}$ $B A P+3.0 m g / l$ IAA has shown the maximum response and produced healthy plantlets.
\end{abstract}

Key words - Croton scabiosus, embryo culture, mass multiplication, population augmentation.

\section{Introduction}

Most of the plants do not have potential regenerative capacity in natural habitats because of various problems. Different techniques for conservation of plants have been practiced worldwide; most importantly the tissue culture [1]. In this context, in vitro culture of plants has gained importance during recent years because of its feasibilities as an ex situ conservative measure through rapid multiplication of plantlets in a limited time boundary. Micropropagation has become been a great potential tool to overcome problems related with the field culture for which are having low regenerative capacity [2]. Euphorbiaceae members are well known for their medicinal, timber ornamental and other ecosystem values. Several workers have been succeeded with micropropagation studies on members of Euphorbiaceae: Euphorbia esula [3], Phyllanthus stipulatus [4], Jatropha curcas [5], Croton sublyratus [6], Croton urucurana [7], Cleistanthus collinus [8] and especially somatic embryogenesis with Codieum variegatum [9] and Euphorbia pulcherima. [10].

Embryo culture is the aseptic isolation and in vitro growth of an embryo under optimum culture conditions which helps in overcoming the post fertilization barriers of hybridization in woody plant species [11]. Croton scabiosus Bedd., the candidate species of the present work is a small deciduous tree, endemic to southern Andhra Pradesh. The species represent isolated small populations with scattered distribution in dry deciduous forests of southern Andhra Pradesh [12]. Seeds of this plant in the local area are used as an antidote for snake bite and scorpion sting and different vegetative parts found to have a diversity of secondary metabolites - alkaloids, coumarins, glycosides, flavonoids, steroids, and gallic tannins [13]. As Croton scabiosus is having very attractive silvery or golden foliage this species may also recommended as an ornamental garden plant [14]. The species population is threatened in the native habitat primarily by recurrent fires and secondarily by seed pathology and poor germination. As a result the population numbers are coming down and warranting the suitable conservation measures. Perusal of literature has revealed that micropropagation studies have not been attended on Croton scabiosus. Hence the present study has been attempted to develop a protocol for mass multiplication of this endemic medicinal plant through embryo culture. The present study focus on standardizing an in vitro embryo culture by using different media (MS, $\mathrm{B}_{5}$, and WPM) containing $3 \%(\mathrm{~W} / \mathrm{V})$ sucrose, $0.8 \%$ (W/V) agar- agar and different concentrations of plant growth regulators. May this study can contribute in conservation management of this endemic plant species.

\section{Materials And Methods}

Lab experimentation was carried out in Plant Tissue Culture Laboratory, Department of Botany, Sri Krishnadevaraya University, Anantapur, and Andhra Pradesh, India.

\subsection{Materials}

Croton scabiosus Bedd. the candidate species for the present embryo culture experiment. It is a small deciduous tree growing up to $5-7 \mathrm{~m}$. The species can be easily recognized in the native habitat as the leaves on both surfaces and inflorescence clothed with sub-silvery lepidote scales and having globose or sub-globose 3lobed capsules. 


\subsection{Explants source}

The fruits of Croton scabiosus were collected from the representative population in dry deciduous forest of Guvvalacheruvu (N - 14 $18^{\circ} 35^{\prime \prime}$ E - 78 46' 0.93"), located in Kadapa district, Andhra Pradesh State, India. The representative specimens were deposited in S. K. University Herbarium, Anantapur.

\subsection{Media formulation for embryo culture}

Media formulation was carried by using three types of media i.e. MS, $\mathrm{B}_{5}$, and WPM. Of the three media used, MS medium has shown good results and hence adopted for experimentation. MS medium [16] was prepared by amending 3\% of Sucrose (Merck, India) as stable carbon source with different cytokinins, BAP (6Benzyl amino purine), and 2 ip (2- iso pentanyl adenine) varying from $0.5 \mathrm{mg} / \mathrm{l}$, to $3.25 \mathrm{mg} / \mathrm{l}$. Same concentrations were adopted for the auxins, IAA (Indole 3- Acetic Acid), and NAA (Naphthalene acetic acid). Single hormonal concentration along with the combinational concentration has been prepared. The $\mathrm{P}^{\mathrm{H}}$ was adjusted to 5.6-5.8, with $1 \mathrm{~N} \mathrm{NaOH}$, and $1 \mathrm{~N} \mathrm{HCL}$ then $0.8 \%$ of agar-agar (Himedia, India) was added and melted at $100^{\circ} \mathrm{c}$ for $2-3$ minute. Then the media was poured into the culture tubes and autoclaved at $121^{\circ} \mathrm{c}$ at 15 psi for 15 minute. After the sterilization of media, the culture tubes were placed in a cool chamber for solidification.

\subsection{Sterilization of seeds}

The fresh and healthy fruits were collected as explants source and dried. From the dried fruits, the seeds were collected to get mature embryos. The seed coat was found very hard and more than 15 days was taken for complete drying. Dried seeds were thoroughly washed with running tap water for more than 30 minutes. $2 \%$ of Labolien added as surfactant and washed with running tap water and then with de-ionized water with vigorous shaking. Then the seeds were soaked for overnight. Alternative soakings was carried out for softening the seed coat. Soaked seeds were sterilized with surfactant and de-ionized water for more than 15 minute. The remaining sterilization procedure was carried out under Laminar Air flow cabinet. The seeds were washed with sterilized de-ionized water in order to remove all the remnants of the surfactants. Sterilization was tested with two different sterilants, i.e. Mercuric Chloride $\left(\mathrm{Hgcl}_{2}\right)$ 0.1\%, 0.3\%, 0.5\%, $1.0 \%$ concentrations and Sodium Hypochlorite (Naocl) in $5 \%, 10 \%, 20 \%, 30 \%$ w/v. Among the sterilants used, Sodium hypochlorite of $30 \%$ showed best results in avoiding contaminations and hence it was used as standard concentration of sterilant for surface sterilization of seeds. $70 \%$ alcohol was used for complete sterilization for 60 seconds. Finally the seeds were rinsed with autoclaved de-ionized water for 6 times.

\subsection{Usage of plant growth regulators}

To assess the effect of plant growth regulators on embryo growth, the embryos were cultured on full strength MS basal medium supplemented with different concentrations of BAP $(0.5,1,1.75,2.5,3.5 \mathrm{mg} / \mathrm{l})$, IAA $(0.5,1,1.75,2.5,3.5 \mathrm{mg} / \mathrm{l}), 2-\mathrm{ip}(0.5,1,1.75,2.5,3.5 \mathrm{mg} / \mathrm{l})$ and NAA $(0.5,1,1.75,2.5,3.5 \mathrm{mg} / \mathrm{l})$. Concentration of plant growth regulators was tested, based on the results obtained in multiple shoot formation from elite and mature explants i.e. internodes and shoot tips of the same species (Data not shown).

MS medium fortified with single hormone has shown that $0.5 \mathrm{mg} / \mathrm{l} \mathrm{BAP}$ is the stable concentration at which $80 \%$ regeneration has been found and hence this is maintained as standard concentration. Combination of low cytokinin and high concentration of auxin promotes the regeneration of embryos without any morphological changes [18]; and hence an attempt has been made to evaluate the suitable concentration of cytokinin + auxin at which notable results can be achieved. IAA and NAA with $1,2,3,4,5 \mathrm{mg} / \mathrm{l}$ were used along with $0.5 \mathrm{mg} / \mathrm{l}$ $\mathrm{BAP}$ and the results were tabulated.

\subsection{Inoculation and incubation}

The sterilized seeds were taken out from Erlin Meyer's bottle and transferred on to the sterilized Petri plates having autoclaved filter papers. The seed coat was cracked with the help a scalpel. By splitting the kernel longitudinally without causing any injury to the embryo and the mature embryos were collected and carefully and transferred on to the sterile nutrient media. The culture tubes were incubated at $25^{\circ} \pm 10^{\circ} \mathrm{c}$ with $16 \mathrm{hrs}$ photoperiod and $8 \mathrm{hrs}$ of darkness at 2000 lux light intensity of cool white fluorescent light (Philips Make). All the experiments were repeated for 4 times and the results were recorded after 10 days of inoculation.

\section{Results}

The seed germination on basal MS medium was observed no results. Hence to get viable plants from Elite germplasm i.e. embryos, it is very necessary to enhance the ability of a medium by supplementing the plant growth regulators. Two different auxins and two of the cytokinin were employed in embryo culture. 


\subsection{Effect of auxins on embryo culture}

IAA and NAA were employed in culturing the embryos of Croton scabiosus in different concentrations from $0.5 \mathrm{mg} / \mathrm{l}$ to $3.5 \mathrm{mg} / \mathrm{l}$. IAA with $1 \mathrm{mg} / \mathrm{l}$ gave good results with $60 \%$ regeneration. All the concentrations used of IAA showed response. NAA is also used to determine the growing ability of embryo. NAA, $1.75 \mathrm{mg} / \mathrm{l} \mathrm{showed}$ $53 \%$ regeneration with viable plants (TABLE-1, Fig. 1). No response was observed on $2.5 \mathrm{mg} / \mathrm{l}$. When compared to the IAA the regeneration of embryos was less and also more number of shoots was not obtained with the both hormones.

\subsection{Effect of cytokinins on embryo culture}

Of the cytokinins used in the present experimentation, BAP and $2 \mathrm{ip}$, low concentration of BAP 0.5 $\mathrm{mg} / \mathrm{l}$ has shown the maximum response. More than $80 \%$ (Fig-1) of response was observed in 3 replicates, with 1-3 shoots from embryo within a short period of time i.e. 10 days. BAP $1 \mathrm{mg} / \mathrm{l}$ also showed the considerable results of embryo culture. Other cytokinin amended to determine the embryo culture was 2 ip. Of the concentrations used, $1.75 \mathrm{mg} / \mathrm{l}$ (TABLE-1) with MS medium resulted more than $66 \%$ of response which is comparatively lower than BAP.

\subsection{Effect of auxin and cytokinin combination on embryo culture}

The results obtained on MS medium fortified with different single plant growth regulators has shown that $0.5 \mathrm{mg} / \mathrm{l} \mathrm{BAP}$ is the suitable concentration at which $80 \%$ regeneration has been achieved. By maintaining this as a standard, different concentrations of auxins were employed to prepare combinational media. IAA and NAA with $1,2,3,4,5 \mathrm{mg} / \mathrm{l}$ were used and the results revealed that, IAA at $3 \mathrm{mg} / \mathrm{l}$ along with the $0.5 \mathrm{mg} / 1 \mathrm{BAP}$ (TABLE-2) is the most suitable concentration for quick and healthy regeneration of embryos, as the response was $90 \%$ within the 4 replicates (10 No's for 1 replication )

The duration of the experiment was 50 days. During the regeneration of embryos on different media significant observations were made with respect to 4 different parameters of embryo regeneration- shoot and root forming embryos; root forming embryos; shoot forming embryos and callus forming embryos. The results were presented in both single and combinational concentrations of hormones (TABLE -3).

TABLES

Table 1: Percentage of response of embryos on different plant growth regulators

\begin{tabular}{|c|c|c|c|c|c|}
\hline $\begin{array}{c}\text { S. } \\
\text { No }\end{array}$ & $\begin{array}{c}\text { Name of the } \\
\text { PGR }\end{array}$ & Conc. Used & $\begin{array}{c}\text { No of embryos } \\
\text { inoculated }\end{array}$ & $\begin{array}{c}\text { No of embryos } \\
\text { responded }\end{array}$ & $\begin{array}{c}\text { percentage } \\
\text { of response }\end{array}$ \\
\hline 1 & BAP & 0.5 & 30 & 24 & 80 \\
\hline & & 1 & 30 & 20 & 66.6 \\
\hline & & 1.75 & 30 & 15 & 50 \\
\hline & & 2.5 & 30 & 7 & 23.3 \\
\hline & & 3.5 & 30 & --- & --- \\
\hline 2 & IAA & 0.5 & 30 & 11 & 36.6 \\
\hline & & 1 & 30 & 18 & 60 \\
\hline & & 1.75 & 30 & 4 & 13.3 \\
\hline & & 2.5 & 30 & 14 & 46.6 \\
\hline & & 3.5 & 30 & 12 & 40 \\
\hline 3 & 2 ip & 0.5 & 30 & 5 & 16.6 \\
\hline & & 1 & 30 & 12 & 40 \\
\hline & & 1.75 & 30 & 20 & 66.6 \\
\hline & & 2.5 & 30 & 7 & 23.3 \\
\hline & & 3.5 & 30 & 10 & 33.3 \\
\hline 4 & NAA & 0.5 & 30 & 6 & 20 \\
\hline & & 1 & 30 & 10 & 33.3 \\
\hline & & 1.75 & 30 & 16 & 53.3 \\
\hline & & 2.5 & 30 & -- & -- \\
\hline & & 3.5 & 30 & 5 & 16.6 \\
\hline
\end{tabular}


Table 2: Percentage of response of embryos in hormonal combinations

\begin{tabular}{|c|c|c|c|c|}
\hline Name of the PGR & Conc. Used & $\begin{array}{c}\text { No of embryos } \\
\text { inoculated }\end{array}$ & $\begin{array}{c}\text { No of embryos } \\
\text { responded }\end{array}$ & $\begin{array}{c}\text { Percentage of } \\
\text { response }\end{array}$ \\
\hline BAP+IAA & 0.5 BAP+1IAA & 40 & 20 & 50 \\
\hline & 0.5 BAP+2IAA & 40 & 24 & 60 \\
\hline & 0.5 BAP+3IAA & 40 & 32 & 90 \\
\hline & 0.5 BAP+4IAA & 40 & 15 & 37.5 \\
\hline & 0.5 BAP+5IAA & 40 & 18 & 45 \\
\hline BAP+NAA & 0.5 BAP+1NAA & 40 & 16 & 40 \\
\hline & 0.5 BAP+2NAA & 40 & 20 & 50 \\
\hline & 0.5 BAP+3NAA & 40 & 23 & 57.5 \\
\hline & 0.5 BAP+4NAA & 40 & 18 & 45 \\
\hline & 0.5 BAP+5NAA & 40 & 15 & 37.5 \\
\hline
\end{tabular}

Table 3: Regeneration types embryos on different plant growth regulators

\begin{tabular}{|c|c|c|c|c|c|c|c|c|c|c|}
\hline & & \multicolumn{3}{|c|}{ No of embryos responded } & \multicolumn{3}{|c|}{ (\%)percentage of response } \\
\hline $\begin{array}{c}\text { Name of } \\
\text { PGR }\end{array}$ & $\begin{array}{c}\text { No of } \\
\text { embryos } \\
\text { inoculated }\end{array}$ & $\begin{array}{c}\text { Total No } \\
\text { of } \\
\text { embryos } \\
\text { responded }\end{array}$ & SRFE & RFE & SFE & CFE & SRFE & RFE & SFE & CFE \\
\hline BAP & 150 & 66 & 42 & 10 & 8 & 6 & 63.6 & 15.15 & 12.12 & 9 \\
\hline IAA & 150 & 59 & 36 & 11 & 8 & 4 & 61 & 18.6 & 13.5 & 6.7 \\
\hline 2 ip & 150 & 54 & 34 & 11 & 6 & 3 & 62.9 & 20.3 & 11.1 & 5.5 \\
\hline NAA & 150 & 37 & 20 & 10 & 5 & 2 & 54 & 27 & 13.5 & 5.4 \\
\hline BAP+IAA & 200 & 109 & 67 & 25 & 10 & 7 & 61.4 & 22.9 & 9.1 & 6.4 \\
\hline BAP+NAA & 200 & 92 & 57 & 19 & 11 & 5 & 61.9 & 20.6 & 11.9 & 5.4 \\
\hline
\end{tabular}

SREF: Shoot and root forming embryos; RFE: Root forming embryos; SEF: Shoot forming embryos;

CFE: Callus forming embryos

Figures

Figure 1: Percentage of response of embryos on different plant growth regulators

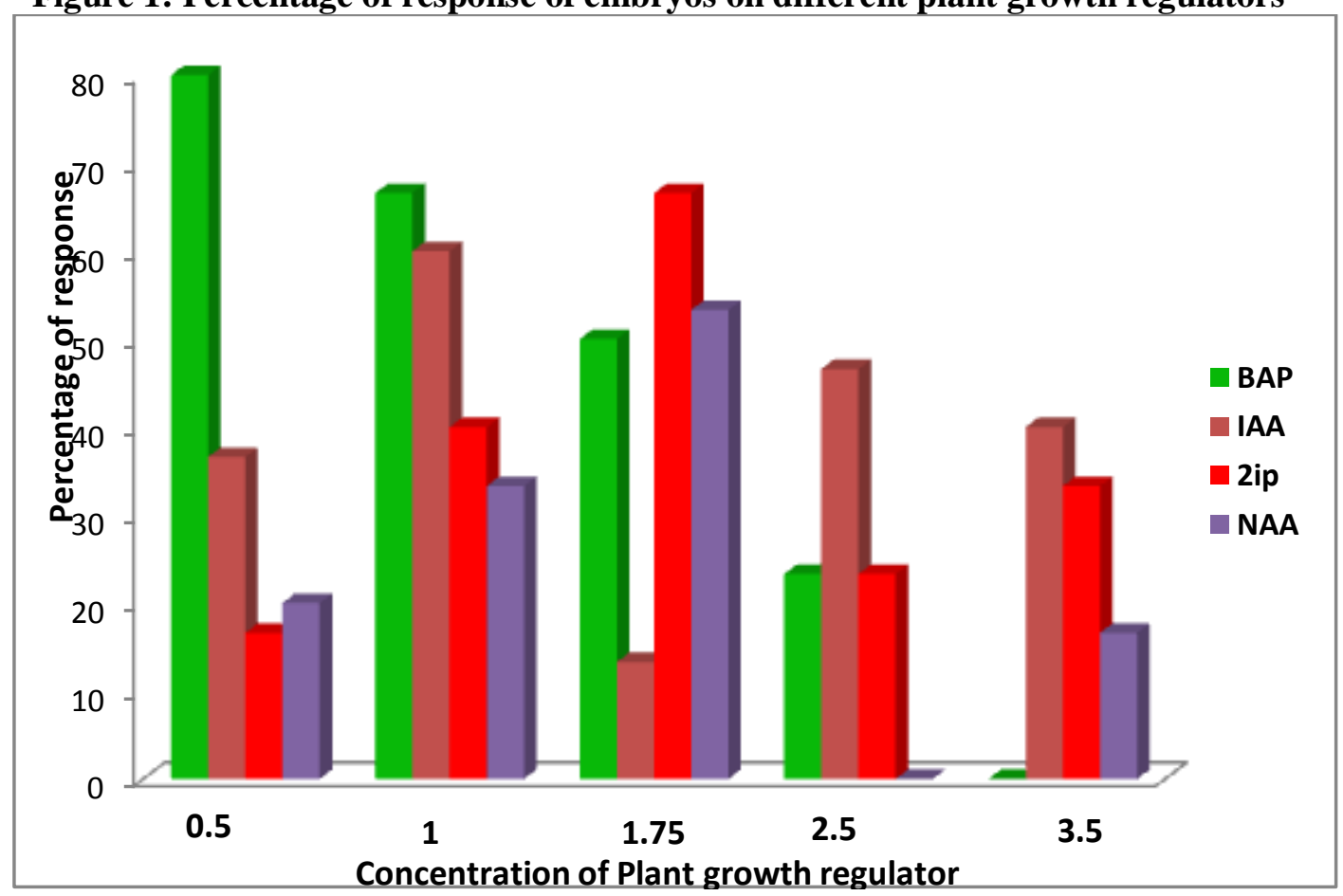


Figure 2: In vitro embryo culture of Croton scabiosus Bedd. from mature embryos

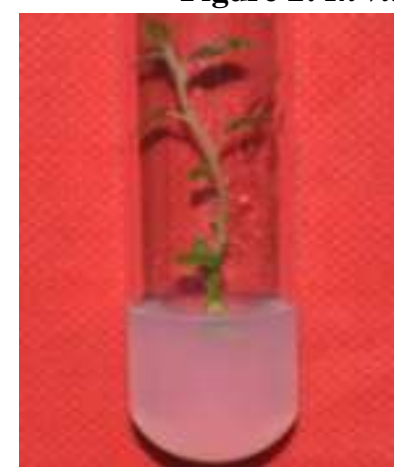

(A)

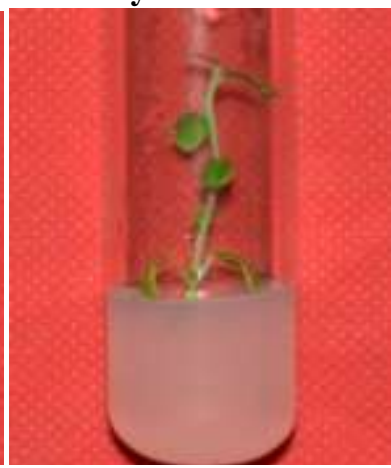

(B)

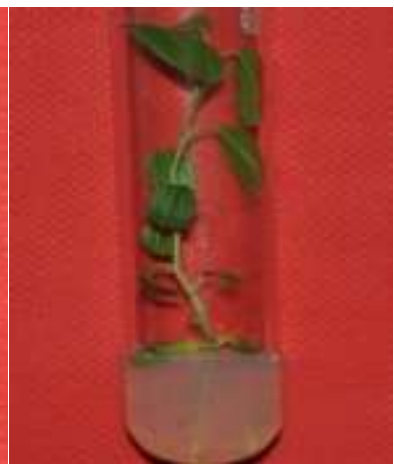

(C)

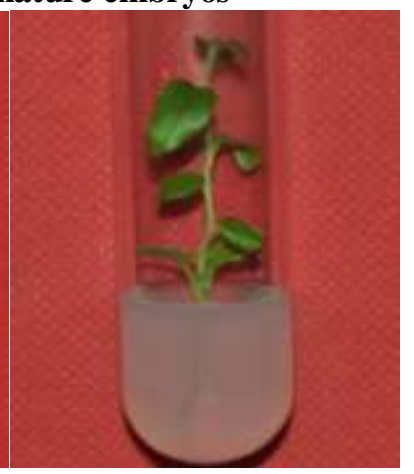

(D)

A) MS+ $0.5 \mathrm{mg} / \mathrm{l}$ IAA- showing shoot formation

B) $\mathrm{MS}+1.75 \mathrm{mg} / \mathrm{l} \mathrm{NAA}$ - showing shoot formation

C) MS+ $1.75 \mathrm{mg} / \mathrm{l} 2 \mathrm{ip}$ - showing both shoot and root formation

D) MS+1 mg/l 2 ip -showing both shoot and root formation

\section{Figure 3: Regenerative pattern of responded embryos}

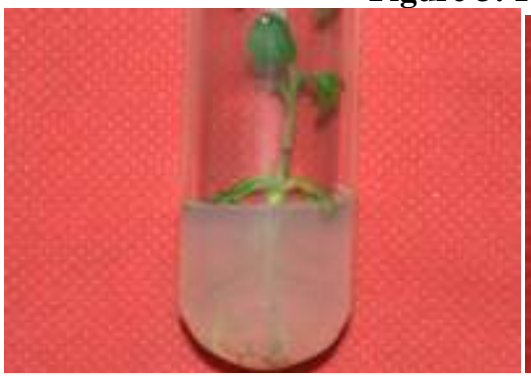

(A)

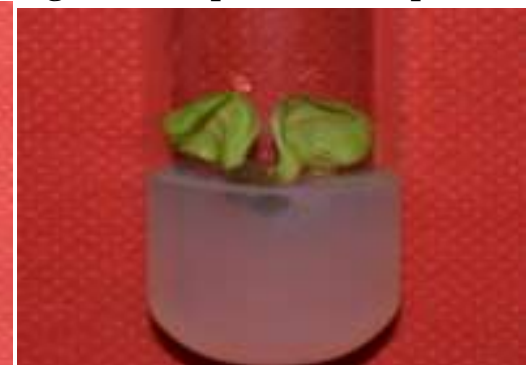

(B)

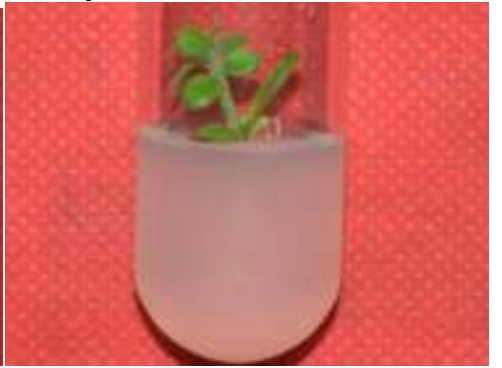

(C)

A) MS+ $0.5 \mathrm{mg} / \mathrm{l} \mathrm{BAP}+2 \mathrm{mg} / \mathrm{lAA}$ - Showing the profuse root formation

B) MS + $1 \mathrm{mg} / \mathrm{l}$ IAA - Showing callus proliferation

C) $\mathrm{MS}+2.5 \mathrm{mg} / \mathrm{BAP}$

Figure 4: Regenerated embryos from plant growth regulators

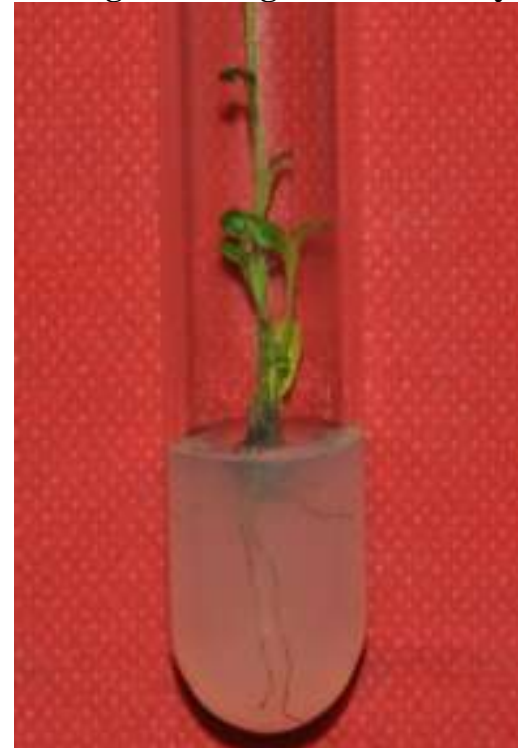

(A)

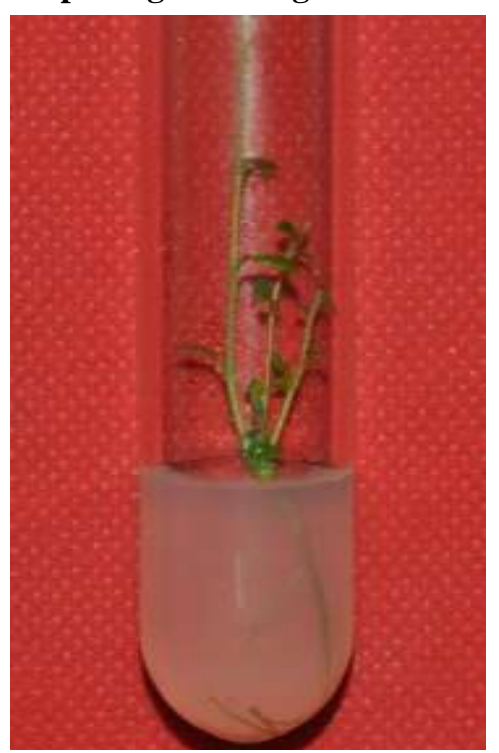

(B)

A) $\mathrm{MS}+0.5 \mathrm{mg} / \mathrm{l} \mathrm{BAP}+4 \mathrm{mg} / \mathrm{l} \mathrm{NAA}$ - showing both shoot and root formation B) $\mathrm{MS}+0.5 \mathrm{mg} / \mathrm{l} \mathrm{BAP}+3 \mathrm{mg} / \mathrm{l}$ IAA- showing multiple shoot and roots 


\section{Discussion}

Croton scabiosus, an endemic of southern Andhra Pradesh warrants immediate conservation measures as the population found at a moderate decline in the natural habitat. With this backdrop, we attempted in vitro propagation, as the seed germination observed very poor even in the garden conditions (data not shown). In vitro propagation by embryo culture is prominent where the problem arises of poor seed viability and pathological issues. Embryo culture results into the formation of complete and viable plantlets to be utilized for mass multiplication of plants to augment existing natural population. During the examination of standardizing sterilant which can prevent the microbial growth during in vitro cultures with two sterilants, i.e. Mercuric Chloride $\left(\mathrm{Hgcl}_{2}\right)$ 0.1\%, 0.3\%, 0.5\%, 1.0\% concentrations and Sodium Hypochlorite (Naocl) in $5 \%, 10 \%, 20 \%$, $30 \% \mathrm{w} / \mathrm{v}$, it was found that Sodium hypochlorite of $30 \%$ showed best results in avoiding contaminations and this concentration was standardized. Hence it was understood that the requirement of sterilant is high to avoid contaminations. Among the three different media used MS medium [16] showed comparably best results than $\mathrm{B}_{5}$ and WPM media. Aseptically separated mature embryos were selected as explants and cultured on agarified MS medium supplemented with different concentrations of auxins and cytokinins. More than $80 \%$ regeneration was found on $0.5 \mathrm{mg} / \mathrm{l}$ BAP. As stated by various plant tissue culturists' low concentration of cytokinin promoted embryo growth development of mature embryos of Croton scabiosus. Apart from the cytokinins, auxins amended to the medium showed considerable results. NAA with $1.75 \mathrm{mg} / \mathrm{l}$ showed $53.3 \%$ of regeneration.

Combination of low cytokinin and high auxin has been utilized for the determination of growth and development rate of embryos. As the $0.5 \mathrm{mg} / \mathrm{l}$ BAP showed the considerable results alone, it has been standardized and the auxins were employed in varying concentrations $(1,2,3,4,5 \mathrm{mg} / \mathrm{l})$. It was noted that $0.5 \mathrm{mg} / \mathrm{l} \mathrm{BAP}+3 \mathrm{mg} / 1 \mathrm{IAA}$ deliberated maximum result up to $90 \%$ by promoting the regeneration of 32 embryos out of 40 inoculated.

Interestingly $3.5 \mathrm{mg} / \mathrm{l}$ of BAP and $2.5 \mathrm{mg} / \mathrm{l}$ of NAA showed no response during the experimentation. This may due to the provided concentration of plant growth regulators may not be in optimum range for embryo regeneration. The results here indicate that exogenously supplied cytokinin along with auxin was enough to promote a hormonal balance, capable of inducing both root and shoot formation from mature embryos of Croton scabiosus.

Four specific observations were recorded the experimentation. More than $60 \%$ (of the total embryos of responded from inoculated embryos) of embryos were able to form shoot and root simultaneously; $20.7 \%$ of embryos showed root formation. Approximately $11.7 \%$ embryos showed the formation of shoots. Of the embryos responded, $6.4 \%$ embryos were found with callus proliferation. These results indicates that the embryos of Croton are able to produce whole healthy plants from which multiplication can be successfully establish for augmentation of plants to its natural and allied habitats. To the best of our knowledge no report is available about micro propagation of Croton scabiosus, and this is the first attempt of standardizing the consistent embryo culture protocol from the mature embryos.

\section{Acknowledgments}

First author greatly acknowledge Department of Science and Technology (DST), Govt. of India for providing financial assistance under 'INSPIRE' Program to carry out this study.

\section{References}

[1] F.M. Parabia, B. Gami, I.L.Kothari, J.S.S.Mohan, and M.H. Parabia, Effect of plant growth regulators on in vitro morphogenesis of Leptadenia reticulata (Retz.) W. Curr. Sci., 92(9), 2007, 1290- 1293.

[2] T. Hidaka and M. Omura, Control of embryogenesis in citrus cell culture regeneration protoplasts and attempts to callus bank. Bulletin of the Fruit tree Research Station, Series Okitsu, 16, 1989, 1-17.

[3] Bin Xu. Wenhao Dai, Wun S.Chao, An efficient method for in vitro regeneration of leafy spurge (Euphorbia esula L.). In Vitro Cell. Dev. Biol.-Plant., 44, 2008, 548-556.

[4] Elizabete catapan, Michel Fleith Otuki and Ana Maria Viana, In vitro culture of Phyllanthus stipulatus (Euphorbiaceae) Revta. brasil. Bot., São Paulo, 24, 2001, 25-34.

[5] Nandini Mohan, Saeid Nikdad, Geetaa Singh, Studies on seed germination and embryo culture of Jatropha curcas L. under in vitro conditions. Biotechnol. Bioinf. Bioeng. 1(2), 2011, 187-194.

[6] Wataru Shibata, Fukashi Murai, Toshiyuki Akiyama, Manoon Siriphol, Eisuke Matsunaga and Hiroyuki Morimoto, Micropropagation of Croton sublyratus Kurza. tropical tree of medicinal importance. Plant Cell Reports, 16, 1996, 147-152.

[7] Ednabel Caracas Lima, Renato Paiva, Raírys Cravo Nogueira, Fernanda Pereira Soares, Eduardo Bucsam Emrich, Álvaro Augusto Naves Silva, Callus induction in leaf segments of Croton urucurana Baill. Ciênc. agrotec., Lavras, 32 ( 1), 2008, 17-22.

[8] Afaque Quraishi., Vijaya Shukla and S.K. Mishra, In vitro micropropagation from nodal segments of Cleistanthus collinus. Plant Cell, tissue and Organ Culture, 45, 1996, 87-91.

[9] Asma Nasib, Kashif Ali and Saifullah Khan, In vitro propagation of Croton (Codiaeum Variegatum), Pak. J. Bot., 40 (I), 2008,99 104.

[10] Yogesh, T. Jasrai, K.N. Thaker and D'Souza, In vitro propagation of Euphorbia pulcherrima Willd. through Somatic embryogenesis. Plant Tissue Cult., 13 (1), 2003, 31-34.

[11] J.M.Bonga, P. Aderkas, In vitro culture of trees, 2(4), 1992, 35-38.

[12] N.P. Balakrishnan and T. Chakrabarthy, The Family of Euphorbiaceae in India (BSMPS Publishers, Dehra Dun, 2007) 
[13] N. Sarojini Devi, J. Mani and R.R. Venkata Raju, In vitro antimicrobial activity and phytochemical constituents of Croton scabiosus Bedd. IJPRD, 3(6), 2011, 149-154.

[14] Neginhal S.G.2004. Forest Trees of South India (Navbharath Press, Bangalore, 2004)

[15] T. Murashige and F. Skoog, A Revised Medium for Rapid Growth and Bioassays with Tobacco, Tissue Culture. Physiol. Plnt., 15, 1962, 473-9.

[16] H. Veen, The effect of various growth-regulators on embryos of Capsella bursapastoris growing in vitro. Acta Bot. Neerl. 12, 1963, 129-171. 